"Does Lending by banks and non-banks differ? Evidence from small business financing"

\begin{tabular}{ll} 
AUTHORS & Joong Ho Han \\
\hline ARTICLE INFO & $\begin{array}{l}\text { Joong Ho Han (2017). Does Lending by banks and non-banks differ? Evidence } \\
\text { from small business financing. Banks and Bank Systems, 12(4), 98-104. } \\
\text { doi:10.21511/bbs.12(4).2017.09 }\end{array}$ \\
\hline DOI & http://dx.doi.org/10.21511/bbs.12(4).2017.09 \\
\hline RELEASED ON & Monday, 27 November 2017 \\
\hline RECEIVED ON & Wednesday, 27 September 2017 \\
\hline ACCEPTED ON & Tuesday, 17 October 2017 \\
\hline LICENSE & $\begin{array}{l}\text { (cc) EY-Nc } \\
\text { This work is licensed under a Creative Commons Attribution-NonCommercial 4.0 } \\
\text { International License }\end{array}$ \\
\hline JOURNAL & "Banks and Bank Systems" \\
\hline ISSN PRINT & $1816-7403$ \\
\hline ISSN ONLINE & $1991-7074$ \\
\hline PUBLISHER & LLC “Consulting Publishing Company "Business Perspectives" \\
\hline FOUNDER & LLC “Consulting Publishing Company "Business Perspectives" \\
\hline
\end{tabular}

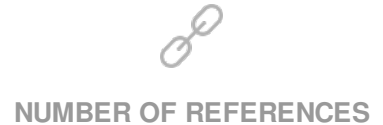

13

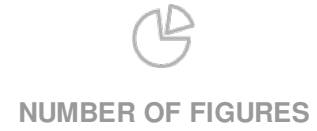

0
NUMBER OF TABLES

3

(C) The author(s) 2023. This publication is an open access article. 


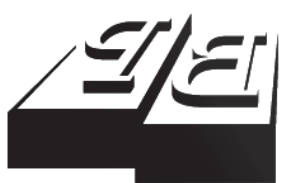

BUSINESS PERSPECTIVES

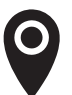

LLC "CPC "Business Perspectives" Hryhorii Skovoroda lane, 10, Sumy, 40022, Ukraine

www.businessperspectives.org

Received on: $27^{\text {th }}$ of September, 2017 Accepted on: $17^{\text {th }}$ of October, 2017

(C) Joong Ho Han, 2017

Joong Ho Han, Ph.D. in Finance, Associate Professor, School of Business, Sungkyunkwan University, South Korea.

\section{DOES LENDING BY BANKS AND NON-BANKS DIFFER? EVIDENCE FROM SMALL BUSINESS FINANCING}

\begin{abstract}
Non-bank loans to corporate businesses have shown a dramatic increase compared to bank loans. Despite the increasing importance of non-bank lending, the differences between loans made by different types of lenders are mostly unknown. To uncover the distinctions, the author investigates whether bank and non-bank financial institutions deal differently with information scarcity of small firms by introducing lender-borrower distance as a proxy for information availability.

Using the National Survey of Small Business Finances (NSSBF) provided by the Federal Reserve Board, the loan approval probability models after controlling for various borrower characteristics are estimated. The NSSBF data is collected by using stratified sampling to ensure sufficient numbers of observations for minority-owned firms. To circumvent potential bias due to the sampling method, the author follows the approach suggested by Wooldridge (1999) and estimates a weighted maximum likelihood estimation to adjust for sampling design.

This paper establishes novel evidence supporting the notion that banks and non-bank financial institutions are different in their ability to deal with information scarcity. Bank loan approval probability decreases as distance to their borrowers increases, while its effect on non-bank loan approval probability is statistically insignificant, supporting the notion that non-bank lending is different from bank lending in dealing with information asymmetry.
\end{abstract}

\section{Keywords}

JEL Classification banks, non-banks, distance, information availability, credit availability

\section{INTRODUCTION}

Non-bank loans to corporate businesses have shown a dramatic increase compared to bank loans since the 1980's (Acharya, et al. 2013; Adrian \& Ashcraft, 2012; Bengtsson, 2013; Careyat al. 1998; Cheng \& Degryse, 2010; Lu et al. 2015). Although non-bank lending has gained importance, the distinctions between loans made by different types of lenders are not clearly understood. Perhaps for simplicity, prior research on capital structure and debt contracting has focused on the contrasts between private debt and public debt. However, the main questions regarding the distinctive roles of different types of private debt contracts remain mostly unexplored. This paper investigates the following questions to understand the differences between private debt contracts, particularly loans by banks and non-bank financial institutions: Do banks and non-banks deal differently with information scarcity of their borrowers? How can non-bank financial institutions make loans to distant firms with low credit quality, which are less likely to be served by banks? 
These questions arise from two stylized facts. First, non-banks tend to make loans to firms with low credit quality that may not be served by banks (Carey et al., 1998; Denis \& Mihov, 2003). Second, the median distance between non-banks and their borrowing firms is about ten times greater than the distance between banks and their borrowers (Petersen \& Rajan, 2002). Although these differences have been documented separately, it has not been examined how non-bank financial institutions are able to serve the distant firms with lower credit quality.

In this paper, banks are defined as depository financial institutions and non-banks are defined as nondepository financial institutions. Due to this distinction, it may be optimal for banks to create a network of branches to obtain deposits which are relatively inexpensive funding sources. A plurality of branches naturally makes banks geographically closer to their potential borrowers than non-banks. If the increase in distance to borrowers exacerbates information scarcity of borrowing firms, non-banks' specialization in loans to riskier firms located farther away becomes even more puzzling.

Despite the documented differences, the previous research has failed to find evidence supporting the notion that banks and non-banks differ in their ability to deal with information scarcity. There are two possible reasons for this lack of evidence. First, as originally pointed out by Carey et al. (1998), prior research has examined loans to publicly traded large firms, which provide hard information, that is relatively easy to verify without requiring extensive monitoring by lenders in the sense of Stein (2002). Second, it is hard to find an adequate proxy for information availability to capture the differences in lending by the two distinct types of creditors. If the unique role of each type of private lenders stems from their abilities to generate information about informationally problematic borrowers, a good proxy of information availability needs to be closely related with the degree of difficulty in gathering soft information rather than public information availability.

To circumvent the difficulties in the previous research, this paper examines loans to small businesses and introduces the geographical distance between these small firms and their lenders as a proxy for information availability. If banks and non-banks behave differently when it comes to financing informationally opaque firms, the contrasts between their loans are more likely to be pronounced in small business financing than in large, publicly traded firm financing. Therefore, a dataset containing loans to small firms will provide an adequate testing ground for identifying the differences between bank and non-bank lending practices. On the other hand, Petersen and Rajan (1994) point out the possibility that the lenders located closer to their borrowers suffer less from information scarcity. Moreover, the distance from borrowing firms is at least partially exogenous to creditors. Recent research by Gaspar and Massa (2007) has documented evidence consistent with the claim that increase in geographical distance can cause acute information asymmetry in the U.S. financial market. Following their approaches, the author uses lender-borrower distance as a proxy variable for information scarcity and investigates its asymmetric impacts on bank and non-bank loan pricing and availability.

This paper provides the first comprehensive evidence supporting the notion that banks and non-banks are different in their ability to deal with the information scarcity of their borrowers. The author finds that the loan approval probability of banks decreases as distance to borrowers increases, whereas the effect for non-bank loans is not statistically significant. These findings are consistent with the claim that banks are monitoring-specialized lenders that price their loans based on marginal monitoring costs, which increase with distance to their borrowers, while non-banks use a distinct lending technology less constrained by information scarcity aggravated by an increased distance to borrowers.

In the next section of this paper, the author discusses the extant literature. Section 2 provides a brief description of data. Section 3 investigates whether loans by banks and non-bank financial institutions are different and explains the implications of the findings. Section 4 concludes the paper. 


\section{LITERATURE REVIEW}

Only a few empirical studies have examined the difference between bank and non-bank loans. Carey et al. (1998) agree that ex-ante observably riskier firms are more likely to be served by finance companies than by commercial banks. They estimate the lender-type prediction model by including proxies for both observable risk and information availability. They find no definite evidence that the proxies for information availability explain the choice between banks and finance companies even though they find that proxies for observable risk are statistically significant and the results are robust. Denis and Mihov (2003) also examine how firms choose among different types of debt, and find that lowest credit quality firms borrow from non-banks. These findings support that non-banks are specialized in serving risky firms compared to banks, but fail to show whether banks and non-banks actually use different lending technologies for their borrowers. This paper contributes to this literature by documenting the first comprehensive evidence consistent with the distinct lending functions of banks and nonbanks.

\section{DATA}

The author's primary data source is the 1993 National Survey of Small Business Finances (hereafter, NSSBF) provided by the Federal Reserve Board. The reason for using 1993 NSSBF instead of 1998 and 2003 NSSBFs is that the differences between bank and non-bank financial institutions in the U.S. financial markets are blurred in the late 1990s. Specifically, the introduction of the 1999 Financial Services Modernization Act abolished the restrictions on banks and non-bank financial institutions entering into each other's business areas. Therefore, using 1993 NSSBF data provides a unique testing ground for whether bank lending and non-bank lending differ in terms of their abilities to deal with information asymmetry.

To be included in this NSSBF, firms must hire fewer than 500 employees. This survey data includes detailed information on the borrowing firms' characteristics and the most recent loans made to these small firms. The author considers for-profit financial institutions for the analysis.

Table 1. Summary statistics for loan applicants

\begin{tabular}{|c|c|c|c|c|}
\hline Variable & Mean & $\begin{array}{c}\text { Weighted } \\
\text { mean }\end{array}$ & Mean & $\begin{array}{c}\text { Weighted } \\
\text { mean }\end{array}$ \\
\hline Probability of loan approval & $86(\%)$ & $83(\%)$ & $89(\%)$ & $85(\%)$ \\
\hline Firm age (unit: years) & 15.96 & 13.64 & 15.03 & 12.44 \\
\hline Total assets (unit: \$1,000) & $3,141,051$ & 975,196 & $3,976,769$ & $1,029,734$ \\
\hline Cash to total assets & 0.12 & 0.13 & 0.12 & 0.14 \\
\hline ROA & 0.4 & 0.52 & 0.04 & 0.42 \\
\hline Debt to assets & 0.71 & 0.75 & 0.77 & 0.74 \\
\hline Firm delinquencies & 0.62 & 0.61 & 0.7 & 0.73 \\
\hline Owner delinquencies & 0.28 & 0.31 & 0.44 & 0.59 \\
\hline Financial records used (unit: \%) & $57(\%)$ & $51(\%)$ & $56(\%)$ & $48(\%)$ \\
\hline Distance to borrowers (unit: miles) & 3.39 & 2.51 & 24.82 & 29.71 \\
\hline Applied loan amount to assets & 0.69 & 0.85 & 0.77 & 1.02 \\
\hline Number of creditors & 1.79 & 1.43 & 2.65 & 2.06 \\
\hline Duration of longest relationship (unit: years) & 10.78 & 9.83 & 9.85 & 8.35 \\
\hline Herfindahl - Hirschman Index $=1$ if $H H I>1,800$ & $52(\%)$ & $56(\%)$ & $46(\%)$ & $53(\%)$ \\
\hline Corporation & $46(\%)$ & $34(\%)$ & $42(\%)$ & $31(\%)$ \\
\hline MSA $(=1 / 0)$ & $77(\%)$ & $73(\%)$ & $87(\%)$ & $85(\%)$ \\
\hline Checking account used & $81(\%)$ & $79(\%)$ & - & - \\
\hline Line of credit used & $58(\%)$ & $48(\%)$ & $23(\%)$ & $13(\%)$ \\
\hline Number of obs. & 1,423 & - & 158 & - \\
\hline
\end{tabular}

Note: Each observation represents an approved/disapproved most recent loan application and only applications made after financial information is available are included. Weighted mean is calculated by using the 1993 NSSBF sampling weights. 
Therefore, the sample includes loans made by commercial banks, savings banks, credit unions, finance companies, insurance companies, brokerage firms, leasing companies and mortgage banks. ${ }^{1}$ Including loans made before accounting information is released can generate reverse causality problem because accounting numbers related to small firms are influenced by additional financing through the approved loan applications rather than the accounting information affects creditors' decision to provide capital to their loan applicants. To avoid this problem, the author analyzes only the most recent loans made after 1992, the fiscal year when accounting information is collected. The final sample includes 1.581 loan applications (1.224 approved loan contracts). The NSSBF data is collected by using stratified sampling to ensure sufficient numbers of observations for minority-owned firms. This procedure requires sample statistics adjusted for sampling weights to analyze their population properties. All the estimates in this paper are calculated by using weighted estimation procedures (Wooldridge, 1999; Woodruff, 1952).

The author introduces lender-borrower distance as a proxy for information availability and investigates the asymmetric effect of the increase in distance on bank and non-bank loan approval decisions. Loans made by banks and nonbanks show a significant difference in distance to borrowers. The average distance to non-bank borrowers is 29.71 miles, while that to bank borrowers is 2.51 miles (see Table 1). This discrepancy may indicate that banks and non-banks use distinct lending technologies. However, this can also be generated solely from the difference in the number of branches between banks and non-banks. For example, if firms, banks, and non-banks are distributed uniformly across the country and firms choose their lenders randomly, on average, non-banks become located farther away from their customers due to the relatively small number of non-bank branches in the credit market. Although Petersen and Rajan (2002) examine whether lender type predicts distance to borrowers, this may not differentiate the effect of distinct lending practices from the effect of number of branches. In this section, to provide direct evidence concerning the difference in ability to cope with information scarcity, we examine whether an increased distance limits either banks' or non-banks' ability to make loans to informationally opaque small firms.

\section{RESULTS}

This paper estimates the following probit model:

$$
\begin{aligned}
& \operatorname{Pr}(\text { Loan Approval })=f\left(b_{0}+b_{1} \cdot \text { DIST }+\right. \\
& +b_{2} \cdot \text { Credit Quality Proxies }+ \\
& +b_{3} \cdot \text { Information Proxies }+ \\
& b_{4} \cdot \text { Credit Market Concentration }+ \\
& +b_{5} \cdot \text { Relationship Lending }+ \\
& + \text { Region Dummies and Industry Dummies }),
\end{aligned}
$$

where Loan Approval is set to 1 for approval and 0 for disapproval. DIST is defined as the distance between a loan applicant and its potential lender. Proxies for credit quality of borrowing firms include two dummy variables for both past delinquency history of the firm and its owner, and Return on Assets (ROA). Information proxies include the distance between a firm and its creditor and a dummy variable for whether the firm's financial records were used to fill out the NSSBF survey. The summary statistics show that nonbank borrowers are riskier than bank borrowers, confirming the results from previous literature. Non-bank borrowers are, on average, delinquent on their obligations more frequently than bank borrowers. Moreover, the ROA for non-bank borrowers is lower than that for bank borrowers.

Table 2 presents the estimates for the bank and non-bank loan approval probability models. The model is estimated via a fixed-effect probit regression. The author controls for both one-digit industry- and region-fixed effects and uses a weighted maximum likelihood estimation to adjust for sampling design.

The main dimension of information availability

1 This paper excludes venture capitalists here since lending practices of venture capitalists might be signicantly different from non-bank financial institutions. 
in this paper is the distance between small firms and their lenders. Previous research has used different information proxies such as the number of years during which accounting information on a firm is available in COMPUSTAT and a dummy for whether financial records were used to fill out the NSSBF survey (Carey et al., 1998; Petersen \& Rajan, 2002). These proxies are introduced to measure the availability of hard information about loan applicants. In this paper, we implicitly assume that the foremost costs of making loans to informationally opaque small firms are on-going monitoring costs which increase with the distance to borrowing firms, since the information about such small firms will be difficult to be hardened in the sense of Stein (2002).

If banks and non-banks are not significantly different in dealing with information scarcity, the availability of both bank and non-bank loans would be affected by the increase in distance to borrowers in a similar manner. In this case, the observed difference in the distance may be driven by a relatively large number of bank branches in the U.S. credit market. In contrast, if the bank loan availability starts to decrease faster than nonbank loan availability, this would indicate that at least a portion of the observed difference in the lending distance results from distinct lending practices of banks and non-banks. Contrary to the null hypothesis, the results in Table 2 and Table 3 show that for bank loans, the loan approval probability gets lower in greater distance to borrowers, while non-bank loan availability is not affected by the increase in distance to borrowers.

In Table 2, the author estimates a probit regression introducing a dummy variable for whether a lender type is bank (=1) or non-bank (=0) and its interaction term with distance to its borrower. After controlling for various firm and credit market characteristics, the author finds that the increase in distance to borrowers decreases bank loan approval probability, while there is no such effect for non-bank loan availability.

To alleviate the strong restrictions on the coefficients on control variables, the author estimates separate probit regressions for each subsample for bank loan applications and non-bank loan applications and tests the null hypothesis that there is no difference between the impacts of lender-borrower distance on loan availability. The t-test shows that the null hypothesis is rejected at a significant level of 0.05 . The main finding remains unaffected.

Table 2. Distance to borrowers and credit availability

\begin{tabular}{|c|c|}
\hline Variable & Marginal effects \\
\hline \multirow{2}{*}{ DIST (unit: 10 miles) } & 0.002 \\
\hline & $(0.003)$ \\
\hline \multirow{2}{*}{ Bank DummyгDIST } & $-0.016^{* *}$ \\
\hline & $(0.007)$ \\
\hline \multirow{2}{*}{ Bank Dummy } & $-0.500^{*}$ \\
\hline & $(0.261)$ \\
\hline \multirow{2}{*}{ In(Firm age) } & 0.209 \\
\hline & $(0.139)$ \\
\hline \multirow{2}{*}{$\ln$ (Assets) } & $0.182^{* * *}$ \\
\hline & $(0.040)$ \\
\hline \multirow{2}{*}{ ROA } & 0.040 \\
\hline & $(0.024)$ \\
\hline \multirow{2}{*}{ Debt to assets } & 0.025 \\
\hline & $(0.051)$ \\
\hline \multirow{2}{*}{ Cash to assets } & $0.917^{* *}$ \\
\hline & $(0.385)$ \\
\hline \multirow{2}{*}{ Firm delinquency } & $-0.094^{* *}$ \\
\hline & $(0.055)$ \\
\hline \multirow{2}{*}{ Owner delinquency } & $-0.264^{* * *}$ \\
\hline & $(0.069)$ \\
\hline \multirow{2}{*}{ Corporation $(=1 / 0)$} & -0.115 \\
\hline & $(0.126)$ \\
\hline \multirow{2}{*}{ Financial records $(=1 / 0)$} & 0.094 \\
\hline & $(0.123)$ \\
\hline \multirow{2}{*}{ Checking account $(=1 / 0)$} & -0.162 \\
\hline & $(0.165)$ \\
\hline \multirow{2}{*}{ Line of credit used $(=1 / 0)$} & $0.941^{* * *}$ \\
\hline & $(0.150)$ \\
\hline \multirow{2}{*}{ Ln(1+number of lenders) } & -0.181 \\
\hline & $(0.125)$ \\
\hline \multirow{2}{*}{ In(1+ relationship duration) } & 0.176 \\
\hline & $(0.138)$ \\
\hline \multirow{2}{*}{$\mathrm{HHI}>1.800(=1 / 0)$} & 0.065 \\
\hline & $(0.130)$ \\
\hline \multirow{2}{*}{ Metropolitan areas $(=1 / 0)$} & $-0.362^{* *}$ \\
\hline & $(0.166)$ \\
\hline Pseudo $\mathrm{R}^{2}$ & 0.277 \\
\hline Number of obs. & 1.581 \\
\hline
\end{tabular}

Note: This table displays marginal effects from estimating region- and industry-fixed effect probit models where the dependent variable is a dummy variable for bank loan approval. Each observation is the most recent loan in the 1993 National Survey of Small Business Finance. The number in the parentheses represents a standard deviation. Industry (one-digit SIC) and region-fixed effects are controlled. The unit for DIST is 10 miles. Symbols ${ }^{*},{ }^{* *},{ }^{* * *}$ indicate statistical significance at the $0.10,0.05$, and 0.01 levels, respectively. 
Table 3. Robustness

\begin{tabular}{|c|c|c|c|}
\hline Variable & Banks & Non-banks & $\left(\mathrm{H} 0: \beta_{\text {Bank }, 2}=\beta_{\text {Non-bank, } 2}\right)$ \\
\hline \multirow{2}{*}{ DIST (unit: 10 miles) } & $-0.014^{* *}$ & 0.003 & 0.014 \\
\hline & $(0.006)$ & $(0.004)$ & - \\
\hline \multirow{2}{*}{ In (Firm age) } & 0.209 & 1.245 & 0.191 \\
\hline & $(0.143)$ & $(0.781)$ & $-\ldots$ \\
\hline \multirow{2}{*}{ In (Assets) } & $0.187^{* * *}$ & $0.404^{* *}$ & 0.184 \\
\hline & $(0.042)$ & $(0.158)$ & - \\
\hline \multirow{2}{*}{ ROA } & 0.036 & $0.303^{* * *}$ & 0.009 \\
\hline & $(0.024)$ & $(0.1)$ & - \\
\hline \multirow{2}{*}{ Debt to assets } & 0.025 & 0.134 & 0.767 \\
\hline & $(0.051)$ & $(0.367)$ & $-\ldots$ \\
\hline \multirow{2}{*}{ Cash to assets } & $0.776^{* *}$ & $6.050 * * *$ & 0.008 \\
\hline & $(0.394)$ & $(1.963)$ & $\ldots$ \\
\hline \multirow{2}{*}{ Firm delinquency } & $-0.115^{* *}$ & $0.542 * *$ & 0.012 \\
\hline & $(0.058)$ & $(0.257)$ & $-\ldots$ \\
\hline \multirow{2}{*}{ Owner delinquency } & $-0.231 * * *$ & $-1.457 * * *$ & 0.002 \\
\hline & $(0.076)$ & $(0.381)$ & $-\ldots$ \\
\hline \multirow{2}{*}{ Corporation (= 1/0) } & -0.129 & 0.907 & 0.094 \\
\hline & $(0.132)$ & $(0.606)$ & - \\
\hline \multirow{2}{*}{ Financial records $(=1 / 0)$} & 0.075 & -0.261 & 0.518 \\
\hline & $(0.129)$ & $(0.505)$ & \\
\hline \multirow{2}{*}{ Checking account $(=1 / 0)$} & -0.165 & $-\ldots$ & \\
\hline & $(0.164)$ & - & - \\
\hline \multirow{2}{*}{ Line of credit used $(=1 / 0)$} & $0.922 * * *$ & $5.080^{* *}$ & 0.05 \\
\hline & $(0.152)$ & $(2.117)$ & - \\
\hline \multirow{2}{*}{ Ln (1+number of lenders) } & -0.197 & -0.247 & 0.937 \\
\hline & $(0.128)$ & $(0.625)$ & - \\
\hline \multirow{2}{*}{ In (1+ relationship duration) } & 0.185 & -1.477 & 0.069 \\
\hline & $(0.143)$ & $(0.903)$ & - \\
\hline \multirow{2}{*}{$\mathrm{HHI}>1,800(=1 / 0)$} & 0.036 & $1.423^{* *}$ & 0.043 \\
\hline & $(0.137)$ & $(0.674)$ & - \\
\hline \multirow{2}{*}{ Metropolitan areas $(=1 / 0)$} & $-0.342^{* *}$ & $-2.877^{* *}$ & 0.043 \\
\hline & $(0.174)$ & $(0.674)$ & - \\
\hline Pseudo $R^{2}$ & 0.276 & 0.587 & - \\
\hline Number of obs. & 1,423 & 158 & - \\
\hline
\end{tabular}

Note: This table displays marginal effects from estimating region- and industry-fixed effect probit models where the dependent variable is a dummy variable for bank loan approval. Each observation is the most recent loan in the 1993 National Survey of Small Business Finance. The number in the parentheses represents a standard deviation. Industry (one-digit SIC) and regionfixed effects are controlled. The unit for DIST is 10 miles. Symbols ${ }^{*}{ }^{* *},{ }^{* *}$ indicate statistical significance at the $0.10,0.05$, and 0.01 levels, respectively.

\section{CONCLUSION}

Much research in banking and corporate finance has investigated the trade-off between private debt and public debt. However, research on distinct types of private debt is relatively rare. To understand the potential difference in lending by banks and non-bank financial institutions, the author investigates the following questions: Is lending by banks and non-banks different? If so, how can non-banks serve distant firms with low credit quality which may not be served by banks?

This paper establishes evidence supporting the notion that banks and non-bank financial institutions are different in their ability to deal with information scarcity. Bank loan approval probability decreases as distance to their borrowers increases, while its effect on non-bank loan approval probability is statistically insignificant. This finding suggests that bank lending is more constrained by an increased distance to borrowers than non-bank lending, indicating that non-banks specialize in a different type of lending technology which depends less on the information about their borrowers. 


\section{REFERENCES}

1. Acharya, V. V., Khandwala, H., \& Sabri Öncü, T. (2013). The growth of a shadow banking system in emerging markets: Evidence from India. Journal of International Money and Finance, 39(Supplement C), 207-230. https://doi. org/10.1016/j.jimonfin.2013.06.024

2. Adrian, T., \& Ashcraft, A. B. (2012). Shadow Banking Regulation. Annual Review of Financial Economics, 4(1), 99-140. https:// doi.org/10.1146/annurev-financial-110311-101810

3. Bengtsson, E. (2013). Shadow banking and financial stability: European money market funds in the global financial crisis. Journal of International Money and Finance, 32(Supplement C), 579-594. https://doi.org/10.1016/j.jimonfin.2012.05.027

4. Carey, M., Post, M., \& Sharpe, S. A (1998). Does Corporate Lending by Banks and Finance Companies Differ? Evidence on Specialization in Private Debt Contracting. The Journal of Finance, 53(3), 845-878. https://doi.org/10.1111/00221082.00037
5. Cheng, X., \& Degryse, H. (2010). The Impact of Bank and NonBank Financial Institutions on Local Economic Growth in China. Journal of Financial Services Research, 37(2), 179-199. https://doi. org/10.1007/s10693-009-0077-4

6. Denis, D. J., \& Mihov, V. T. (2003). The choice among bank debt, non-bank private debt, and public debt: evidence from new corporate borrowings. Journal of Financial Economics, 70(1), 3-28. https://doi.org/10.1016/S0304405X(03)00140-5

7. Gaspar, J.-M., \& Massa, M. (2007). Local ownership as private information: Evidence on the monitoring-liquidity trade-off. Journal of Financial Economics, 83(3), 751-792. https://doi. org/10.1016/j.jfineco.2005.10.010

8. Lu, Y., Guo, H., Kao, E. H., \& Fung, H.-G. (2015). Shadow banking and firm financing in China. International Review of Economics \& Finance, 36(Supplement C), 40-53. https://doi.org/10.1016/j. iref.2014.11.006
9. Petersen, M. A., \& Rajan, R. G. (1994). The Benefits of Lending Relationships: Evidence from Small Business Data. The Journal of Finance, 49(1), 3-37. https://doi. org/10.2307/2329133

10. Petersen, M. A., \& Rajan, R. G. (2002). Does Distance Still Matter? The Information Revolution in Small Business Lending. The Journal of Finance, 57(6), 2533 2570. https://doi.org/10.1111/15406261.00505

11. Stein, J. C. (2002). Information Production and Capital Allocation: Decentralized versus Hierarchical Firms. The Journal of Finance, 57(5), 1891-1921. https://doi. org/10.1111/0022-1082.00483

12. Woodruff, R. S. (1952). Confidence Intervals for Medians and Other Position Measures. Journal of the American Statistical Association, 47(260), 635-646. https://doi. org/10.2307/2280781

13. Wooldridge, J. M. (1999). Asymptotic Properties of Weighted M-estimators for variable probability samples. Econometrica, 67(6), 1385-1406. https://doi. org/10.1111/1468-0262.00083 